\title{
The Optimum One-year-old Shoot Length to Optimize Yield and Fruit Size of Three Fig (Ficus carica L.) Cultivars
}

\author{
Hein J. Gerber, Willem J. Steyn, and Karen I. Theron ${ }^{1}$ \\ Department of Horticultural Science, University of Stellenbosch, Private Bag \\ X1, Matieland 7602, South Africa
}

Additional index words. optimum shoot length

\begin{abstract}
The European fig cultivars Bourjasotte Noire, Col de Damme Noire, and Noire de Caromb were recently introduced to the Western Cape Province of South Africa. Producers struggle to implement effective commercial practices that will optimize yield of quality fruit. A phenological study was conducted to establish the optimum 1-year-old shoot length to maximize yield. The number of fruit, budbreak, and shoot growth on 1year-old shoots comprising four length categories ('Bourjasotte Noire': 10 to 15, 25 to 40, 50 to 65, and 75 $+\mathrm{cm}$; 'Col de Damme Noire' and 'Noire de Caromb': 10 to 20, 30 to 50, 60 to 80 , and $100+\mathrm{cm}$ ) were evaluated. In 'Bourjasotte Noire', all four categories seem to be suited for reproduction in the current season and also provide sufficient new shoot growth to ensure a fair yield the next season. In 'Col de Damme Noire', category four seems to be the best 1-year-old shoot length for reproduction both in terms of fruit number and fruit size. However, yield on these shoots may not be optimal the next season, because current-season shoots are too short. It seems that this cultivar will require pruning to stimulate strong new shoot growth that will ensure regular, high yields. In 'Noire de Caromb', category one shoots are very productive relative to their length. Categories two and three were also relatively productive, whereas category four was less productive but developed a large number of current-season shoots similar in length to category one that should be productive the next season. These results will allow us to develop pruning strategies to ensure an optimal balance between current-season yield and the development of new fruiting wood to ensure regular, high yields. It also suggests that the three cultivars studied will require differential application of horticultural practices to attain regular, high yields of large fruit.
\end{abstract}

The common fig (Ficus carica L.) is a subtropical, deciduous fruit tree (Botti et al., 2003) belonging to the Eusyce subgenus of the Moraceae (mulberry) family (Mars, 2003; Watson and Dallwitz, 2004). Figs are cultivated in most Mediterranean-type climates (Flaishman et al., 2008) with the Mediterranean basin of primary importance (Şahin, 1998). Despite possibly being the oldest cultivated fruit species (Brown, 1994), a lack of information pertaining to production practices as well as the low number of fig cultivars available commercially limit global expansion of fig cultivation (Botti et al., 2003). Even so, the commercial production of figs has expanded to the Mediterranean-type climate Western Cape Province of South Africa, where three black,

Received for publication 12 May 2010. Accepted for publication 29 June 2010 .

This material is based on work supported by Alterna Fruit and the National Research Foundation under Grant number 2069401.

Any opinions, findings and conclusions or recommendations expressed in this material are those of the authors and do not necessarily reflect the views of the National Research Foundation.

This article forms part of a thesis submitted by Hein J. Gerber in partial fulfilment of the MScAgric degree requirements.

${ }^{1}$ To whom reprint requests should be addressed; e-mailkit@sun.ac.za. parthenocarpic, common-type figs, 'Bourjasotte Noire', 'Col de Damme Noire', and 'Noire de Caromb', have been established to provide fruit for the fresh market in South Africa and Europe.

Common-type figs produce their main crop from buds in the axils of leaves on the current season's growth (Flaishman et al., 2008; McEachern, 1996). Harvest may start in the middle of summer and can last several months until the onset of winter. At the end of the growth period, trees enter into a dormant period preceded by leaf drop. Fig buds require little or no winter chilling to break endodormancy (Ferguson et al., 1990) and growth resumes in early spring (Flaishman et al., 2008). Fig shoots have one vegetative and two reproductive buds per node, the shoot ending in a vegetative bud.

Shoots on 'Bourjasotte Noire' display plagiotropic to weak orthotropic growth, resulting in open, drooping trees. 'Noir de Caromb' displays orthotropic growth resulting in a more upright but spreading tree, whereas 'Col de Dame Noire' shoots grow strongly orthotropic resulting in a more upright, compact but large tree. 'Bourjasotte Noire' and 'Col de Damme Noire' display strong apical dominance (AD); therefore, new proleptic $(\mathrm{N}+1)$ shoots develop mainly from the most distal vegetative buds of 1-year-old (N) shoots. As a result, large sections of "blind wood" are found on strong N shoots (personal observation). 'Noire de Caromb' has less pronounced (moderate to strong) $\mathrm{AD}$ (as is often the case in breba cultivars) than the other two cultivars. 'Col de Damme Noire' grows extremely vigorously followed by 'Noire de Caromb' and then 'Bourjasotte Noire' (personal observation).

To maximize yield of good-quality fruit, the most productive shoot lengths (in terms of yield and fruit size) should be determined and strategies devised to maximize the number of these shoots on trees on an annual basis. It is therefore important to study the phenological characteristics of a cultivar to establish optimum shoot characteristics. The objective of this research was to identify the most suitable types of shoots by selecting distinctly different $\mathrm{N}$ shoots on the tree and doing a detailed, comparative study of phenological processes such as budbreak, shoot growth, and yield for each shoot length category.

\section{Materials and Methods}

The study was conducted on 'Bourjasotte Noire', 'Col de Damme Noire', and 'Noire de Caromb' trees during the 2008-2009 growing season in a 4-year-old commercial orchard in the Breede River valley (Mediterranean-type climate; lat. $33^{\circ} 34^{\prime} \mathrm{S}$, long. $19^{\circ} 16^{\prime} \mathrm{E}, 217 \mathrm{~m}$ ) near Worcester in the Western Cape, South Africa. The area accumulated 541.5 chill units from 1 May 2008 until 31 Aug. 2008 according to the Daily Positive Chill Unit model (Linsley-Noakes et al., 1995). The trees, on own roots, were planted in Oct. 2004 at a spacing of $4 \times 3 \mathrm{~m}$

Four different $\mathrm{N}$ shoot length categories were selected and tagged per tree ('Bourjasotte Noire': 10 to 15,25 to 40,50 to 65 , and $75+\mathrm{cm}$; 'Col de Damme Noire' and 'Noire de Caromb': 10 to 20,30 to 50,60 to 80 , and $100+\mathrm{cm}$ ) using 12 single uniform trees per cultivar. The length and basal diameter of each of the 12 tagged shoot per category were measured. The average $\mathrm{N}$ shoot lengths of the four shoot categories from the shortest (category 1) to the longest (category 4) shoots were as follows: 'Bourjasotte Noire': 14.0, 38.4, 60.8, and $85.3 \mathrm{~cm}$; 'Col de Damme Noire': 17.9, 44.3, 74.7, and $121.1 \mathrm{~cm}$; and 'Noire de Caromb': $16.8,44.1,73.0$, and $113.6 \mathrm{~cm}$.

All trees received standard commercial practices except that tagged shoots were left unpruned. The selected shoots were evaluated in terms of the following parameters: total number of vegetative buds on $\mathrm{N}$ shoots; budbreak over time; number of $\mathrm{N}+1$ shoots and their individual lengths; number of reproductive buds on $\mathrm{N}+1$ shoots; number of fruit harvested per shoot; weight and diameter of harvested fruit; and fruit scars on $\mathrm{N}+1$ shoots. Fruit scars were counted as a comparison with the number of harvested fruit in case some fruits were inadvertently picked or lost.

Comparison of parameters per $\mathrm{N}$ shoot length category were done by analysis of variance using the general linear models procedure of SAS Version 9.1.3 SP2 (SAS Institute, Cary, NC). Single df, orthogonal polynomial contrasts were fitted where applicable. 


\section{Results}

'Bourjasotte Noire'. The average number of new shoots $(\mathrm{N}+1)$ produced (which also represents budbreak) per 1-year-old $(\mathrm{N})$ shoot increased linearly from category one $(\mathrm{C} 1)$ to four (C4) with $\mathrm{C} 1$ yielding an average of 1.6 shoots per $\mathrm{N}$ shoot compared with $\mathrm{C} 4$ yielding 8.8 shoots (Table 1). Budbreak percentage on $\mathrm{N}$ shoots increased linearly from $24.5 \%$ to $39.2 \%$ from $\mathrm{C} 1$ to $\mathrm{C} 4$ (Table 1 ).

The total length of new $\mathrm{N}+1$ growth increased linearly from $\mathrm{C} 1$ to $\mathrm{C} 4$. $\mathrm{C} 1$ shoots produced an average of $18 \mathrm{~cm}$ new growth as compared with $\mathrm{C} 4$ shoots, which produced an average of $152 \mathrm{~cm}$ (Table 1). The average $\mathrm{N}+1$ shoot length increased linearly from $\mathrm{C} 1$ $(11.4 \mathrm{~cm})$ to $\mathrm{C} 4(17.9 \mathrm{~cm})$ (Table 1). The average length of $\mathrm{N}+1$ shoots that yielded fruit likewise increased linearly from $\mathrm{C} 1$ to $\mathrm{C} 4$. There was a linear increase in internode length from $\mathrm{C} 1$ to $\mathrm{C} 4$ (Table 1).

Total fruit per $\mathrm{N}$ shoot followed a linear $(P<0.0001)$ to slightly quadratic $(P=$ 0.0883 ) trend with $\mathrm{C} 1$ producing only 2.3 fruit per shoot in comparison with $\mathrm{C} 4$ shoots producing 9.3 fruit. In fruit scars per $\mathrm{N}$ shoot, the quadratic trend is confirmed $(P=0.0354)$ and $\mathrm{C} 1$ produced significantly fewer fruit than all other categories. Yield (gram) per $\mathrm{N}$ shoot increased linearly from $\mathrm{C} 1$ to $\mathrm{C} 4$ shoots (Table 1). There were no significant differences between categories in the average number of fruit per $\mathrm{N}+1$ shoot or the average fruit weight or diameter (Table 1). All $\mathrm{N}+1$ shoots from the four categories used in the study were pooled per category to investigate the correlation of shoot length and diameter with the number of fruit produced. The number of fruit per shoot increased linearly with increasing length $\left(R^{2}=0.861\right)$ and diameter $\left(R^{2}=0.873\right)$ of shoots (Fig. 1).

The occurrence of $\mathrm{N}+1$ shoots and their fruiting characteristics were evaluated per $\mathrm{N}$ shoot length category and expressed in graphs (Fig. 2A-D). The length of $\mathrm{N}+1$ shoots ranged from 0.1 to $30 \mathrm{~cm}$ on $\mathrm{C} 1$ (A) and $\mathrm{C} 2$ (B) $\mathrm{N}$ shoots, 0.1 to $45 \mathrm{~cm}$ on $\mathrm{C} 3$ (C), and 0.1 to $55 \mathrm{~cm}$ on $\mathrm{C} 4$ (D) shoots (Fig. 2). All of the $\mathrm{N}$ shoots used in this study from $\mathrm{C} 2, \mathrm{C} 3$, and $\mathrm{C} 4$ produced fruit (on new growth), whereas $83 \%$ of $\mathrm{N}$ shoots from $\mathrm{C} 1$ produced fruit (data not shown)

The following percentages of $\mathrm{N}+1$ shoots on each $\mathrm{N}$ shoot category yielded fruit: $68 \%$ (C1), 76\% (C2), 66\% (C3), and 54\% (C4) (Fig. 2). None of the four $\mathrm{N}$ shoot length categories produced fruit on $\mathrm{N}+1$ shoots 0.5 to $4.9 \mathrm{~cm}$ long. In the four categories, respectively, more than $60 \%$ of $\mathrm{N}+1$ shoots of the following length ranges produced an average number of two or more fruit per shoot: 5 to $29.9 \mathrm{~cm}$ in C1 and $\mathrm{C} 2,10$ to $45 \mathrm{~cm}$ in $\mathrm{C} 3$, and 10 to $40 \mathrm{~cm}$ in $\mathrm{C} 4$ (Fig. 2). $\mathrm{C} 1$ and $\mathrm{C} 2 \mathrm{~N}$ shoots produced slightly more fruit on $\mathrm{N}+1$ shoots 5.0 to 14.9 $\mathrm{cm}$ long than $\mathrm{C} 3$ and $\mathrm{C} 4$ (Fig. 2). On average, $\mathrm{C} 3$ produced more fruit on shoots in the range 20.0 to $45.0 \mathrm{~cm}$ long than the other categories. Of all $\mathrm{N}+1$ shoots produced per category, $42 \%, 18 \%, 15 \%$, and $10 \%$ (eight, eight, 11 , and 10 shoots, respectively) were of the same length as $\mathrm{C} 1 \mathrm{~N}$ shoots $(10$ to $15 \mathrm{~cm}$ ) on $\mathrm{C} 1, \mathrm{C} 2, \mathrm{C} 3$, and $\mathrm{C} 4$, respectively. The occurrence of $\mathrm{N}+1$ shoots the length of $\mathrm{C} 2$ shoots $(25$ to $40 \mathrm{~cm}$ ) was $5 \%, 11 \%, 22 \%$, and $26 \%$ (one, five, 17 , and 27 shoots, respectively) on $\mathrm{C} 1, \mathrm{C} 2, \mathrm{C} 3$, and $\mathrm{C} 4$, respectively. Only one $\mathrm{N}+1$ shoot the length of a $\mathrm{C} 3$ shoot (50 to $65 \mathrm{~cm}$ ) was produced (on a $\mathrm{C} 4$ shoot) on the selected shoots over 12 trees in this trial. No $\mathrm{N}+1$ shoots the length of a $\mathrm{C} 4$ shoot were produced in this trial (Fig. 2).

'Col de Damme Noire'. The number of $\mathrm{N}$ +1 shoots (budbreak) per $\mathrm{N}$ shoot increased linearly from $\mathrm{C} 1$ to $\mathrm{C} 4$ in which $\mathrm{C} 1$ produced 1.1 and C4 8.7 shoots, respectively. The budbreak percentage likewise increased linearly from the shortest to the longest category (Table 2).

Total new growth per $\mathrm{N}$ shoot increased linearly from $\mathrm{C} 1$ to $\mathrm{C} 4$. $\mathrm{C} 1$ produced $15 \mathrm{~cm}$ new growth compared with $191 \mathrm{~cm}$ new growth produced by $\mathrm{C} 4$ (Table 2 ). The average length of $\mathrm{N}+1$ shoots showed a quadratic increase $(P=0.0480)$ from $\mathrm{C} 1$ to $\mathrm{C} 3$ and $\mathrm{C} 4$, whereas the average length of $\mathrm{N}+1$ shoots yielding fruit increased linearly from $\mathrm{C} 1$ to C4. In $\mathrm{C} 1$, the average $\mathrm{N}+1$ shoot length was $12.7 \mathrm{~cm}$, whereas the combined average $\mathrm{N}+1$ shoot length of $\mathrm{C} 2$ to $\mathrm{C} 4$ averaged $21.2 \mathrm{~cm}$ (Table 2). The average internode length of $\mathrm{N}$ shoots followed a quadratic trend, increasing sharply from $\mathrm{C} 1$ to $\mathrm{C} 2$ and then more gradually to C4 (Table 2).

The total number of fruit per $\mathrm{N}$ shoot showed a quadratic increase with an increase in $\mathrm{N}$ shoot length. $\mathrm{C} 4$ produced 10.8 fruits per shoot, which was significantly more fruits than C3, C2, and C1 shoots, respectively. Fruit scars and total yield (grams) per $\mathrm{N}$ shoot followed the same pattern (Table 2). There were no significant differences among the four categories in terms of the average number of fruit per $\mathrm{N}+1$ shoot (fruiting and non-fruiting shoots) (Table 2). Both average fruit weight and diameter increased linearly from $\mathrm{C} 1$ to $\mathrm{C} 4$ shoots with $\mathrm{C} 1$ yielding fruit with an average weight and diameter $22.6 \mathrm{~g}$ and $32.1 \mathrm{~mm}$, respectively, whereas the averages of $\mathrm{C} 4$ fruit were $8.7 \mathrm{~g}$ and $5.2 \mathrm{~mm}$ more than the control (Table 2).

When all $\mathrm{N}+1$ shoots were pooled per $\mathrm{N}$ category, a positive linear correlation was found between number of fruit per shoot and shoot diameter $\left(R^{2}=0.986\right)$ as well as shoot length $\left(R^{2}=0.821\right)$ (Fig. 3).

$\mathrm{N}+1$ shoots on $\mathrm{C} 1$ ranged mainly from 0.1 to $40 \mathrm{~cm}$ with one shoot outside this range measuring $67 \mathrm{~cm}$. On $\mathrm{C} 2$, shoots ranged from 0.1 to $35 \mathrm{~cm}$, whereas on $\mathrm{C} 3$ and $\mathrm{C} 4$, they ranged mainly from 0.1 to $55 \mathrm{~cm}$. One shoot of $64 \mathrm{~cm}$ developed on $\mathrm{C} 4$ (Fig. 4). In C1, 75\% of the $12 \mathrm{~N}$ shoots produced fruit (on new growth), whereas $92 \%$ of $\mathrm{N}$ shoots in $\mathrm{C} 2$ and all $\mathrm{N}$ shoots in $\mathrm{C} 3$ and $\mathrm{C} 4$ produced fruit (data not shown). Of all the $\mathrm{N}+1$ shoots produced in $\mathrm{C} 1,77 \%$ yielded fruit followed by $\mathrm{C} 4$ with $74 \%$, then C2 with $67 \%$, and C3 with $52 \%$ (Fig. 4).

$\mathrm{C} 1$ shoots yielded a high number of fruit mostly on $\mathrm{N}+1$ shoots ranging from 5 to 40 $\mathrm{cm}$ in length, apart from one fruit yielding

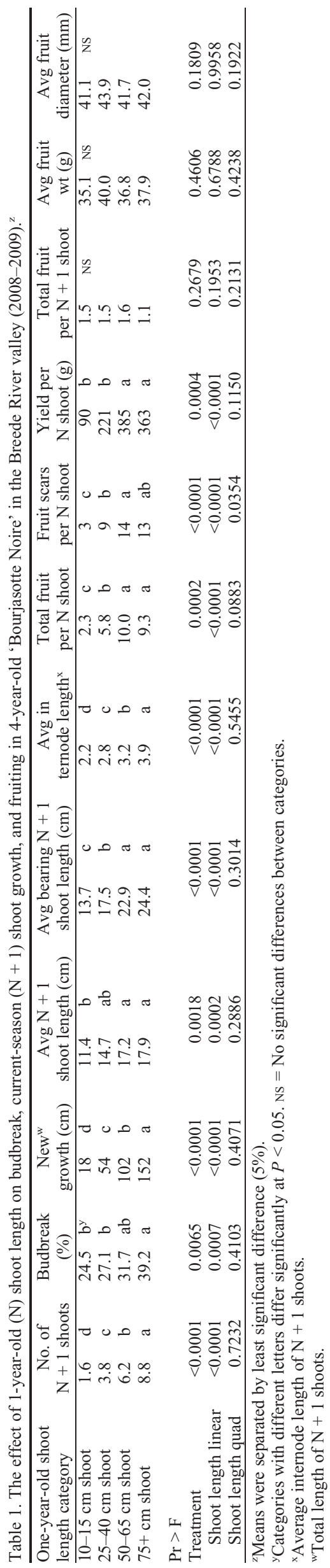

HortScience Vol. 45(9) September 2010 
shoot outside this range measuring $67 \mathrm{~cm}$. More than $60 \%$ of shoots in this range yielded fruit. C2 shoots produced fruit on a high percentage $(60 \%$ and more) of $\mathrm{N}+1$ shoots ranging from 15 to $35 \mathrm{~cm}$ long, whereas $\mathrm{C} 3$ shoots yielded fruit on more than $60 \%$ of $\mathrm{N}+$ 1 shoots 25 to $30 \mathrm{~cm}$ long and 40 to $55 \mathrm{~cm}$ long. C4 shoots produced fruit on $60 \%$ and more of most shoots 5 to $55 \mathrm{~cm}$ long and also on a 64-cm long $\mathrm{N}$ shoot (Fig. 4).

$\mathrm{C} 1$ and $\mathrm{C} 2$ shoots produced a higher average number of fruit on $\mathrm{N}+1$ shoots ranging in length from 5 to $10 \mathrm{~cm}$ as compared with $\mathrm{C} 3$ and $\mathrm{C} 4$. $\mathrm{C} 4$ shoots produced a high percentage of bearing shoots spanning a wide range of
$\mathrm{N}+1$ shoot length categories. Both $\mathrm{C} 1$ and $\mathrm{C} 4$ seem to produce productive shoots over a wide range of shoot lengths, whereas $\mathrm{C} 2$ and $\mathrm{C} 3$ were more varied in the percentage of shoots that yielded fruit.

Of all $\mathrm{N}+1$ shoots produced per category, $31 \%, 44 \%, 25 \%$, and $15 \%$ were of the same length as $\mathrm{C} 1$ (10 to $20 \mathrm{~cm})$ on $\mathrm{C} 1, \mathrm{C} 2, \mathrm{C} 3$, and $\mathrm{C} 4 \mathrm{~N}$ shoots, respectively. The occurrence of $\mathrm{N}+1$ shoots the length of $\mathrm{C} 2(30$ to $50 \mathrm{~cm})$ was $8 \%, 15 \%, 26 \%$, and $35 \%$ of the shoots produced per $\mathrm{C} 1, \mathrm{C} 2, \mathrm{C} 3$, and $\mathrm{C} 4$, respectively. Only two $\mathrm{N}+1$ shoots in the length range of $\mathrm{C} 3 \mathrm{~N}$ shoots occurred in this study, one in $\mathrm{C} 1$ and one in $\mathrm{C} 4$, whereas no $\mathrm{N}+1$

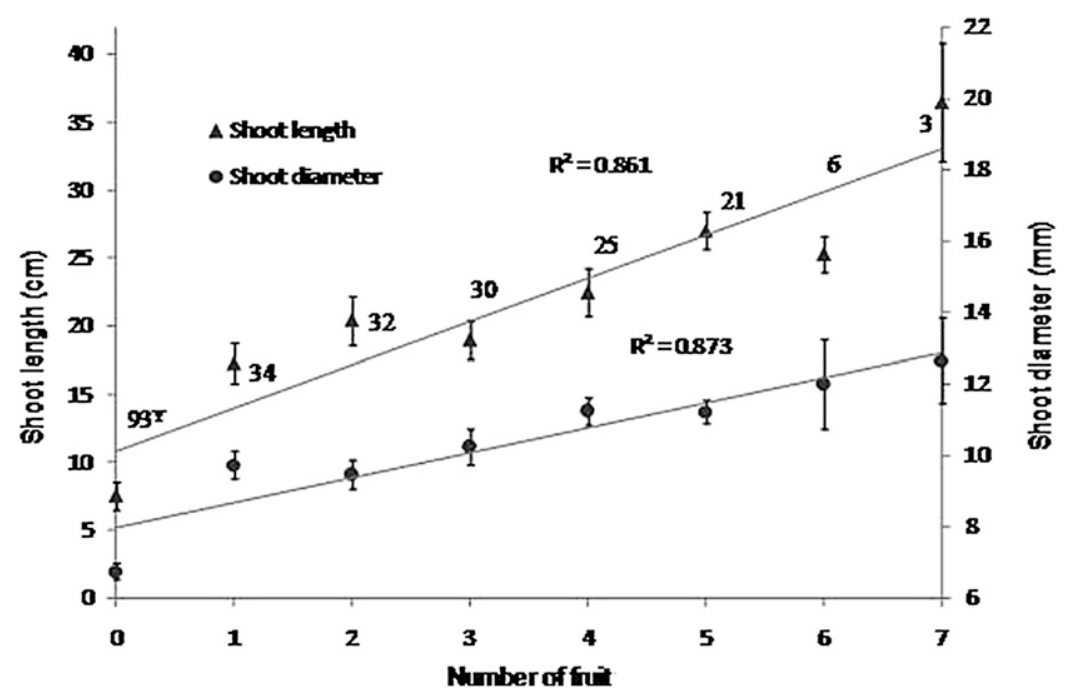

Fig. 1. Relationship between length and diameter of current season shoots and the number of fruits on these shoots in 'Bourjasotte Noire' ('number of shoots within the x-axis category).

shoots in the length range of $\mathrm{C} 4(100+\mathrm{cm})$ were produced (Fig. 4).

'Noire de Caromb'. The number of $\mathrm{N}+1$ shoots (budbreak) and the budbreak percentage both displayed a linear increase from $\mathrm{C} 1$ to $\mathrm{C} 4$. The average number of shoots on $\mathrm{C} 1$ was 1 as compared with 8.5 in $\mathrm{C} 4$ (Table 3). $\mathrm{C} 1$ had $15.5 \%$ budbreak compared $28.4 \%$ budbreak in C4 (Table 3).

The total new growth per $\mathrm{N}$ shoot increased linearly from $\mathrm{C} 1$ to $\mathrm{C} 4$ with $\mathrm{C} 1$ producing only $23-\mathrm{cm}$ growth as compared with $207-\mathrm{cm}$ growth produced by $\mathrm{C} 4$. There was no significant difference between the categories in the average $\mathrm{N}+1$ shoot length produced; however, there was a linear increase in the average length of fruit-bearing shoots from $\mathrm{C} 1$ to $\mathrm{C} 4$ (Table 3). The average length of internodes on $\mathrm{N}$ shoots increased linearly from $\mathrm{C} 1$ to $\mathrm{C} 4$ (Table 3 ).

The total number of fruit per $\mathrm{N}$ shoot increased linearly from $\mathrm{C} 1$ to $\mathrm{C} 4$ with $\mathrm{C} 1$ having on average 2.3 fruits per shoot as compared with $\mathrm{C} 4$ with 6.1. Fruit scars per N shoot displayed a quadratic trend with $\mathrm{C} 1$ and C2 producing significantly fewer fruit per shoot as compared with $\mathrm{C} 3$ and $\mathrm{C} 4$ (Table 3 ). The total yield (grams) per $\mathrm{N}$ shoot increased linearly from $\mathrm{C} 1$ to $\mathrm{C} 4$ (Table 3 ). The total number of fruit per $\mathrm{N}+1$ shoot was significantly higher in $\mathrm{C} 1$ as compared with the other categories, decreasing linearly from $\mathrm{C} 1$ (2.3) to $C 4(0.9)$. There were no significant differences between categories in terms of average fruit weight or diameter (Table 3 ). Like with the other two cultivars, all $\mathrm{N}+1$ shoots in the four categories were pooled to correlate shoot diameter and length to number of fruit (Fig. 5). It was found that the
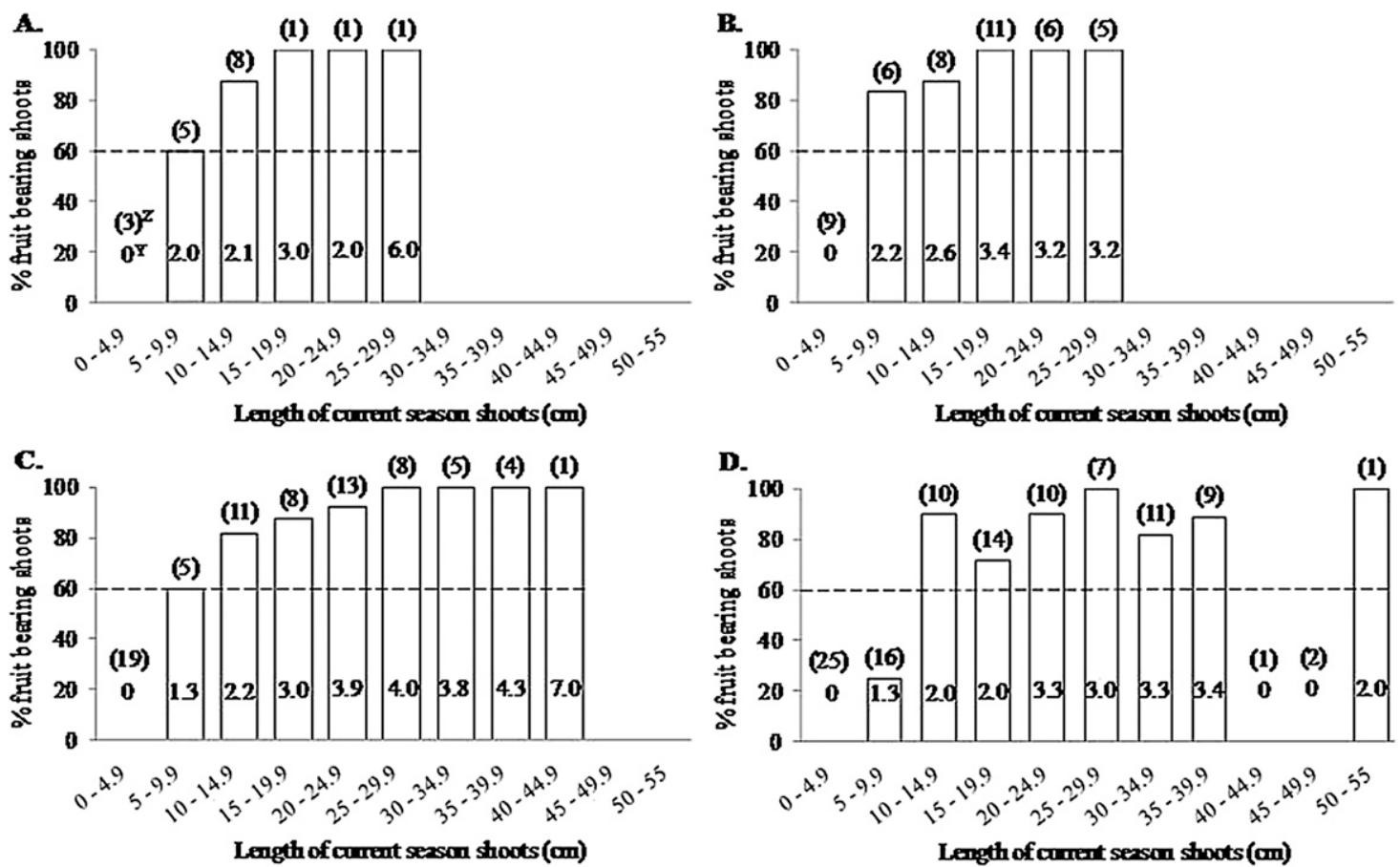

Fig. 2. Characterization of various current season shoot parameters in 'Bourjasotte Noire' ( ${ }^{\mathrm{y}}$ average number of fruit per fruiting shoot; ${ }^{\mathrm{z}}$ total number of shoots in specific category) per category one (A), two (B), three (C), and four (D) 1-year-old shoot length categories. Dashed line at $60 \%$ indicates shoots within specific length categories of which more than $60 \%$ were productive. 


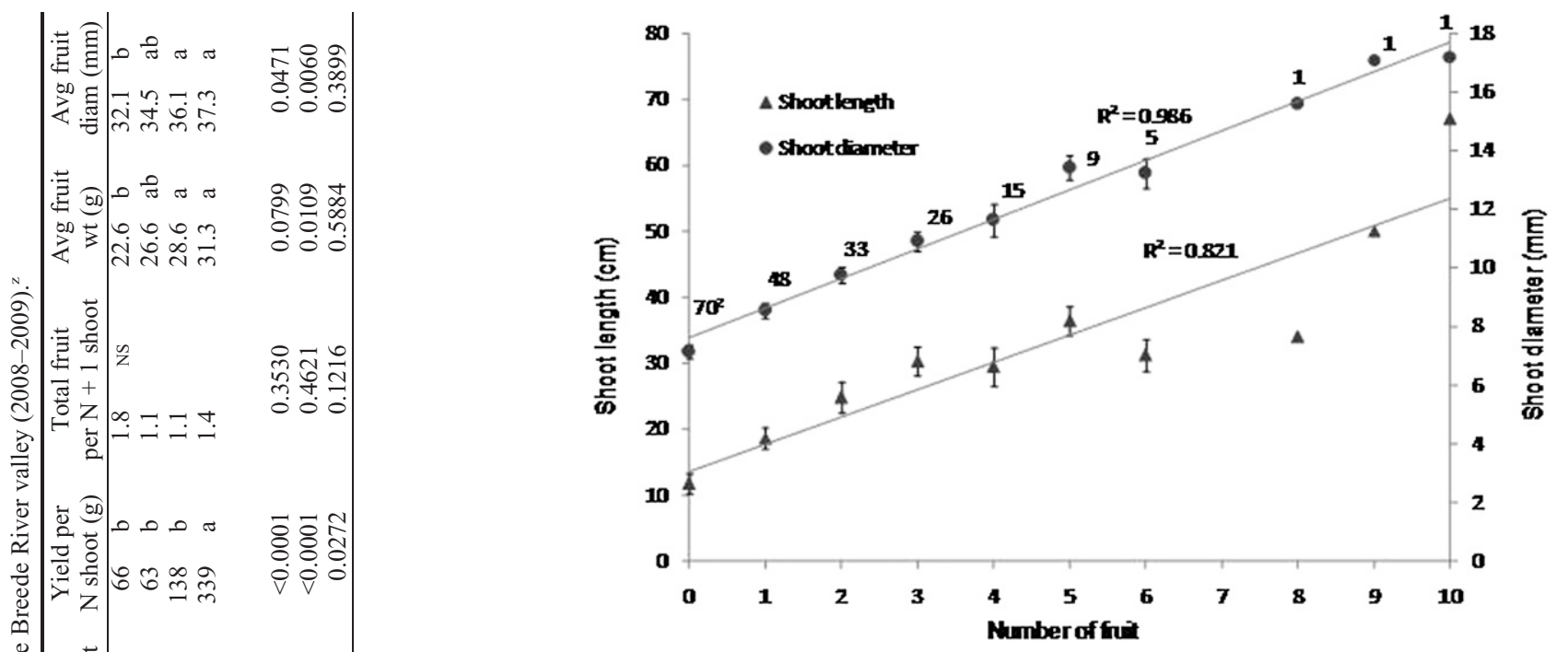

Fig. 3. Response of fruit number to length and diameter of current season shoots in 'Col de Damme Noire' ( ${ }^{\mathrm{z}}$ number of shoots within the $\mathrm{x}$-axis category).

number of fruit increased linearly with an increase in shoot length $\left(R^{2}=0.978\right)$ and diameter $\left(R^{2}=0.946\right)$ (Fig. 5).

The length of $\mathrm{N}+1$ shoots of 'Noire de Caromb' ranged from 5 to $40 \mathrm{~cm}$ in $\mathrm{C} 1,0.1$ to $40 \mathrm{~cm}$ in $\mathrm{C} 2,0.1$ to $60 \mathrm{~cm}$ in $\mathrm{C} 3$ (with an additional shoot $72 \mathrm{~cm}$ long), and 0.1 to 60 cm long in $\mathrm{C} 4$ (Fig. 6). In $\mathrm{C} 1, \mathrm{C} 2$, and $\mathrm{C} 3$, all selected $\mathrm{N}$ shoots produced fruit (on new growth), whereas in C4, $92 \%$ of the $\mathrm{N}$ shoots produced fruit (data not shown). The following percentage of $\mathrm{N}+1$ shoots in the four categories produced fruit: $100 \%, 74 \%, 72 \%$, and $50 \%$ on $\mathrm{C} 1, \mathrm{C} 2, \mathrm{C} 3$, and $\mathrm{C} 4$, respectively.

In $\mathrm{C} 1$, all $\mathrm{N}+1$ shoots 5 to $40 \mathrm{~cm}$ long produced fruit. In $\mathrm{C} 2$, more than $60 \%$ of all shoots 5 to $40 \mathrm{~cm}$ long produced fruit. In C3, more than $60 \%$ of shoots 5 to $40 \mathrm{~cm}$ long and shoots 50 to $60 \mathrm{~cm}$ long plus an additional shoot $71 \mathrm{~cm}$ long produced fruit. In C4, 60\% and more of shoots 25 to $60 \mathrm{~cm}$ long produced fruit (Fig. 6). $\mathrm{C} 1$ produced on average more fruit per $\mathrm{N}+1$ shoot in the 20 - to $40-\mathrm{cm}$ range as compared with other categories (Fig. 6). Of all $\mathrm{N}+1$ shoots produced per $\mathrm{N}$ shoot length category, $0 \%, 18 \%, 14 \%$, and $23 \%$ (zero, seven, nine, and 22 shoots, respectively) were within the length range of $\mathrm{C} 1$ shoots $(10$ to $20 \mathrm{~cm}$ ) on $\mathrm{C} 1, \mathrm{C} 2, \mathrm{C} 3$, and $\mathrm{C} 4 \mathrm{~N}$ shoots, respectively. The occurrence of $\mathrm{N}+1$ shoots the length of C2 (30 to $50 \mathrm{~cm})$ shoots was $25 \%, 21 \%, 28 \%$, and $33 \%$ (four, eight, 18,31 ) of the $\mathrm{N}+1$ shoots produced on $\mathrm{C} 1$, $\mathrm{C} 2, \mathrm{C} 3$, and $\mathrm{C} 4$, respectively (Fig. 6). Only two shoots in the length range of C3 (60 to 80 $\mathrm{cm}$ ) shoots occurred in this study, one on a $\mathrm{C} 3$ and one on a $\mathrm{C} 4$ shoot. $\mathrm{C} 1$ shoots produced $\mathrm{N}+1$ shoots mostly longer than its own length (Fig. 6).

\section{Discussion}

A lower budbreak percentage is expected on longer shoots as a result of the high number of vegetative buds present in comparison with shorter $\mathrm{N}$ units. This was however not the case in any of the three cultivars studied (Tables 1 to 3 ). The shorter average internode length on short $\mathrm{N}$ shoots resulted in more vegetative buds per unit length on shorter shoots (Tables 1 to 3 ) and this probably contributed to the lower budbreak percentages on shorter shoots.

In 'Bourjasotte Noire', the long $\mathrm{C} 4 \mathrm{~N}$ shoots produced the most new growth, but even so, it did not produce more fruit than $\mathrm{C} 3$ despite producing $50 \mathrm{~cm}$ more growth (Table 1). $\mathrm{C} 1, \mathrm{C} 2$, and $\mathrm{C} 3$ produced fruit on a higher percentage of the $\mathrm{N}+1$ shoots in comparison with $\mathrm{C} 4$. C4 seems to be the least productive per unit length when compared with the other categories, although the difference is small. This is probably the result of more vigor resulting in less fruiting (Wertheim, 2005). Even so, $\mathrm{C} 4$ produced the highest number of $\mathrm{N}+1$ shoots of similar lengths as $\mathrm{C} 1, \mathrm{C} 2$, and $\mathrm{C} 3 \mathrm{~N}$ shoots, which should be productive the next season. 'Bourjasotte Noire' did not produce many fruits on $\mathrm{C} 1$ shoots, yet this category is still productive relative to its length when compared with other categories.

In 'Col de Damme Noire', C4 produced the most growth in comparison with the other categories. The total number of fruit and fruit scars followed a quadratic trend, increasing sharply from $\mathrm{C} 1$ and $\mathrm{C} 2$ to $\mathrm{C} 3$ and especially $\mathrm{C} 4$, which yielded the highest number of fruit. The longer $\mathrm{C} 4$ shoots seem to yield the highest number of fruit per $\mathrm{N}$ shoot (and unit length $\mathrm{N}$ shoot) and the fruit are larger making $\mathrm{C} 4$ the most suited for yield in ' $\mathrm{Col}$ de Damme Noir'. C2 is unproductive relative to its size when compared with other categories, and $\mathrm{C} 1$ produces smaller fruit when compared with $\mathrm{C} 3$ and $\mathrm{C} 4$. A large percentage of the $\mathrm{N}+1$ shoots produced by $\mathrm{C} 4$ were the length of $\mathrm{C} 2 \mathrm{~N}$ shoots, the least productive $\mathrm{N}$ shoot length category. None of the categories produced $\mathrm{N}+1$ shoots the length of $\mathrm{C} 4$ shoots.

As was the case in 'Bourjasotte Noire' and 'Col de Damme Noire', the most new growth was produced by $\mathrm{C} 4$ shoots in 'Noire de Caromb'. Even so, the total number of 

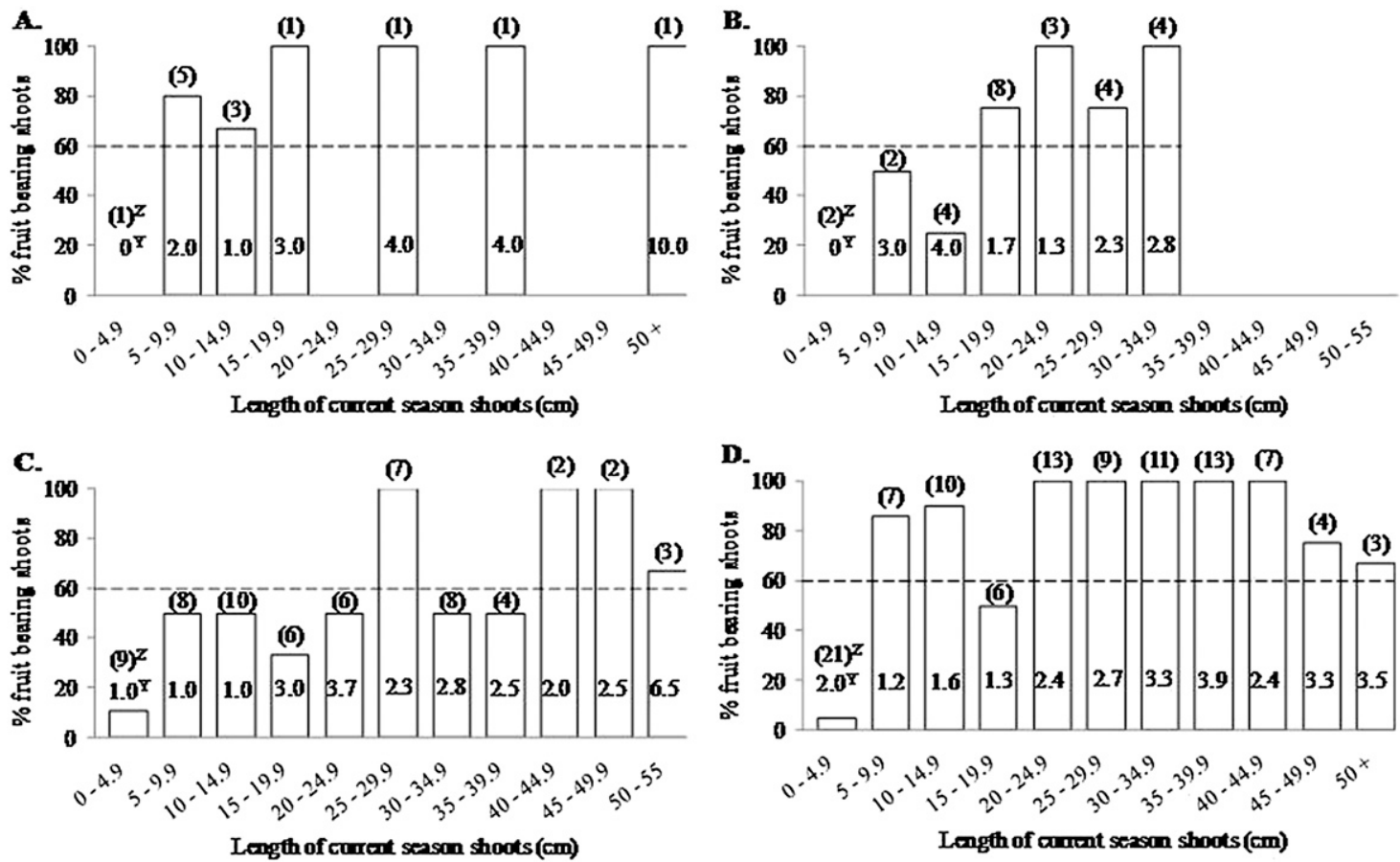

Fig. 4. Characterization of various current season shoot parameters in 'Col de Damme Noire' ('average number of fruit per fruiting shoot; 'total number of shoots in specific category) per category one (A), two (B), three (C), and four (D) 1-year-old shoot length categories. Dashed line at $60 \%$ indicates shoots within specific length categories of which more than $60 \%$ were productive.

Table 3. The effect of 1-year-old $(\mathrm{N})$ shoot length on budbreak, current-season $(\mathrm{N}+1)$ shoot growth, and fruiting in 4-year-old 'Noire de Caromb' in the Breede River valley (2008-2009). ${ }^{2}$

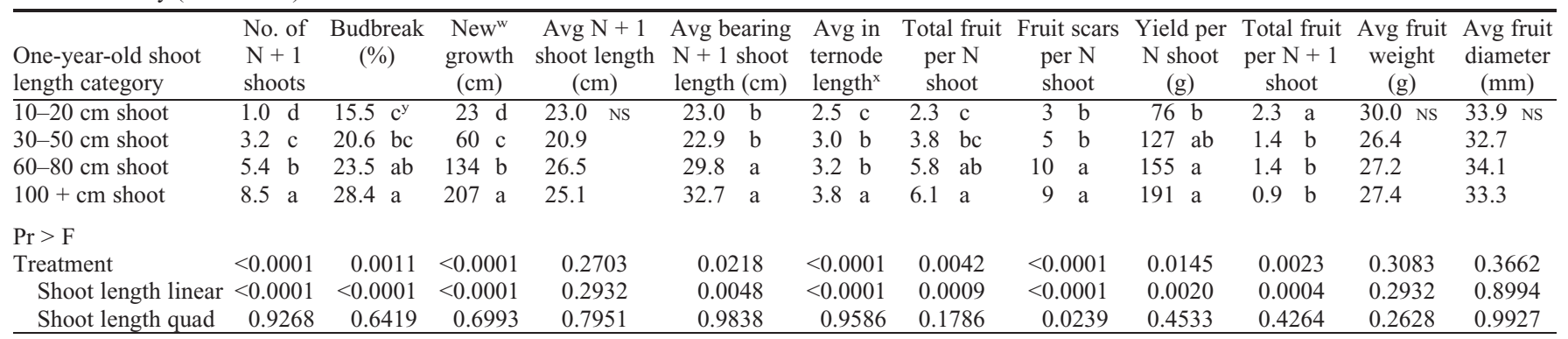

${ }^{\mathrm{z}}$ Means were separated by least significant difference $(5 \%)$.

${ }^{y}$ Categories with different letters differ significantly at $P<0.05$. NS $=$ No significant differences between categories.

${ }^{\mathrm{x}}$ Average internode length of $\mathrm{N}+1$ shoots.

${ }^{w}$ Total length of $\mathrm{N}+1$ shoots.

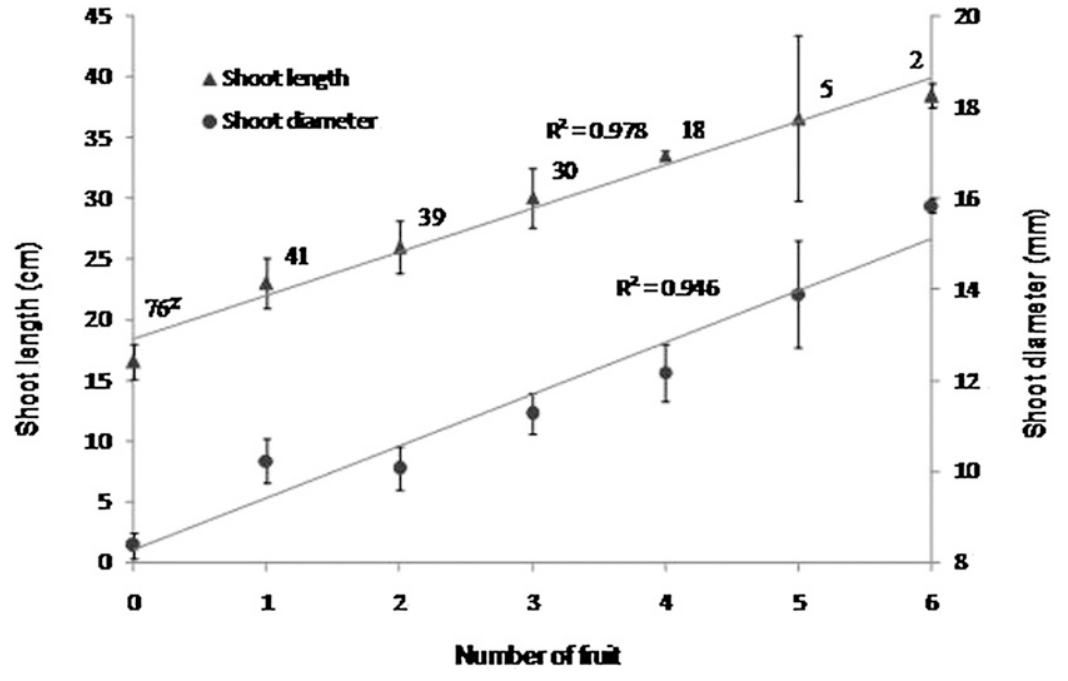

Fig. 5. Response of fruit number to length and diameter of current season shoots in 'Noire de Caromb' ( ${ }^{z}$ number of shoots within the $\mathrm{x}$-axis category). fruit per $\mathrm{N}$ shoot and the number of fruit scars per $\mathrm{N}$ shoot did not differ significantly between $\mathrm{C} 3$ and $\mathrm{C} 4$. It appears that shoot vigor is not detrimental to yield in this cultivar (Wertheim, 2005). The increase in the number of fruit per $\mathrm{N}$ shoot between categories from $\mathrm{C} 1$ to $\mathrm{C} 4$ was low relative to the increase in shoot length.

There was no difference in the average number of fruit per $\mathrm{N}+1$ shoot in 'Bourjasotte Noire' or 'Col de Damme Noire', yet in 'Bourjasotte Noire', C1 and C2 seem to be able to produce more fruit on a higher percentage of $\mathrm{N}+1$ shoots 5 to $15 \mathrm{~cm}$ long in comparison with $\mathrm{C} 3$ and $\mathrm{C} 4$. 'Bourjasotte Noire' has a shorter average bearing shoot length in $\mathrm{C} 1$ and $\mathrm{C} 2$. $\mathrm{C} 3$ and $\mathrm{C} 4$ are mainly productive on $\mathrm{N}+1$ shoots longer than 10 $\mathrm{cm}$. In 'Col de Damme Noire', C1 and C2 seemed to produce more fruit (per shoot) on $\mathrm{N}+1$ shoots 5 to $10 \mathrm{~cm}$ long compared with the other categories. $\mathrm{C} 1$ and $\mathrm{C} 4$ produced 

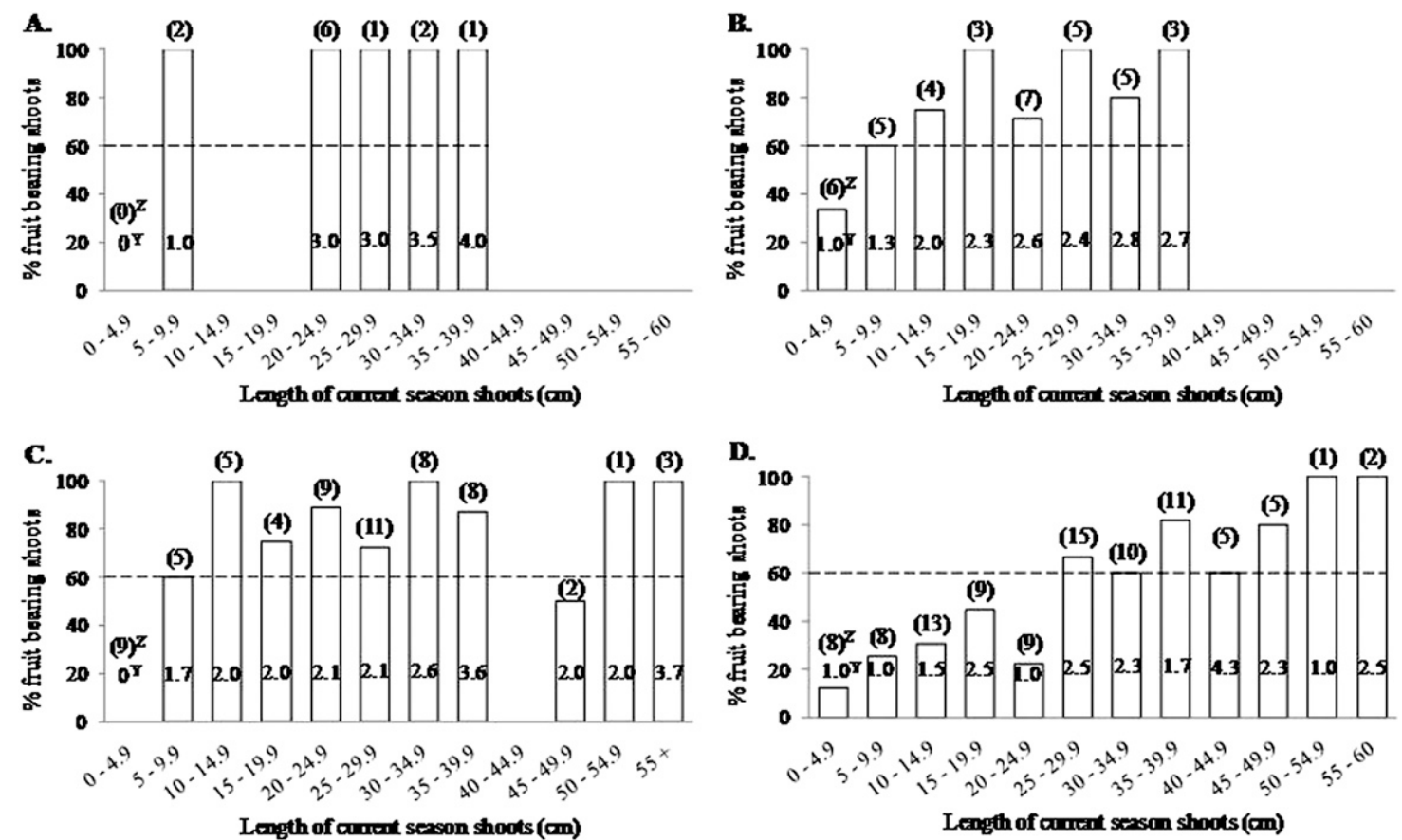

Fig. 6. Characterization of various current-season shoot parameters in 'Noire de Caromb' ('average number of fruit per fruiting shoot; 'total number of shoots in specific category) per category one (A), two (B), three (C), and four (D) 1-year-old shoot length categories. Dashed line at $60 \%$ indicates shoots within specific length categories of which more than $60 \%$ were productive.

fruit more consistently on $\mathrm{N}+1$ shoots in 'Col de Damme Noire' when compared with the other categories. $\mathrm{C} 1$ and $\mathrm{C} 2$ had the shortest average bearing shoot lengths with the average and average bearing shoot lengths of $\mathrm{C} 1$ being equal. In 'Noire de Caromb', it seems that $\mathrm{C} 1$ shoots can produce a higher number of fruit on shorter shoots as compared with the other categories, as seen in Figure 6, and the average "number of fruit produced per $\mathrm{N}+1$ shoot." The percentage of $\mathrm{N}+1$ shoots that yielded fruit in 'Noire de Caromb' was $100 \%, 74 \%, 72 \%$, and $50 \%$ on $\mathrm{C} 1, \mathrm{C} 2, \mathrm{C} 3$, and $\mathrm{C} 4$, respectively; hence, $\mathrm{C} 1$ to $\mathrm{C} 3$ seem to be more productive. Even so, $\mathrm{C} 4$ shoots produced the highest number of $\mathrm{C} 1$ and $\mathrm{C} 2$ shoots that should be productive the next season.

All shoot length categories evaluated yielded fruit in 'Bourjasotte Noire' and produced new shoots that are likely to result in a fair yield in the next season as well. Therefore, minimal pruning should be sufficient. In 'Col de Damme Noire', both $\mathrm{C} 3$ and $\mathrm{C} 4$, but especially $\mathrm{C} 4$, seem to be suited to reproduction, yet they might produce a poor yield the next season because $\mathrm{N}+1$ shoots are too short. Therefore, development of $\mathrm{C} 4$ shoots will have to be stimulated by selective pruning. C1 shoots of 'Noire de Caromb' are productive relative to their length and yield a high average number of fruit per $\mathrm{N}+1$ shoot. C2 and C3 are fairly productive (relative to their size), and $\mathrm{C} 4$ produced suitable shoot lengths for the next season. Not all fig cultivars bear fruit on the same shoot types, but in general, it appears as if a wide range of shoot lengths is productive.

\section{Literature Cited}

Botti, C., N. Franck, L. Prat, and D. Ioannidis. 2003. The effect of climatic conditions on fresh fig fruit yield, quality and type of crop. Acta Hort. 605:37-42.

Brown, P.H. 1994. Seasonal variations in fig (Ficus carica L.) leaf nutrient concentrations. HortScience 29:871-873.
Ferguson, L., T.J. Michailides, and H.H. Shorey. 1990. The California fig industry. Hort. Rev. (Amer. Soc. Hort. Sci.) 12:409-490.

Flaishman, M.A., V. Rover, and E. Stover. 2008. The fig: Botany, horticulture, and breeding. Hort. Rev. (Amer. Soc. Hort. Sci.) 34:113-197.

Linsley-Noakes, G.C., M. Louw, and P. Allan. 1995. Estimating daily positive Utah chill units using daily maximum and minimum temperatures. J. S. Afr. Soc. Hort. Sci. 5:19-22.

Mars, M. 2003. Fig (Ficus carica L.) genetic resources and breeding. Acta Hort. 605:19-27.

McEachern, G.R. 1996. Figs. Aggie Hort. 8 May 2008. $<\mathrm{http}$ ://aggie-horticulture.tamu.edu/extension/ fruit/figs/figs.html>.

Şahin, N. 1998. Fig adaptation studies in Western Turkey. Acta Hort. 480:61-70.

Watson, L. and M.J. Dallwitz. 2004. The families of flowering plants: Descriptions, illustrations, identification and information retrieval. 3 Oct. 2008. <http://delta-intkey.com/angio/>.

Wertheim, S.J. 2005. Pruning, p. 176-189. In: Tromp, J., A.D. Webster, and S.J. Wertheim (eds.). Fundamentals of temperate zone tree fruit production. Backhuys Publishers, Leiden, The Netherlands. 